\title{
TENANT, LODGER, AND GUEST: QUESTIONABLE CATEGORIES FOR MODERN RENTAL OCCUPANTS
}

Population expansion and improved construction methods have vastly changed the character and increased the importance of rental housing. ${ }^{1}$ Hundreds of thousands of families presently occupy multi-unit rental structures of widely varying types. A large number occupy dwelling units in buildings expressly designed for long-term rental, such as garden apartments and residence or apartment hotels, some of which accommodate hundreds of families." Others live in large homes which have been converted into residences for two or more families. Still others reside either temporarily or indefinitely in buildings constructed primarily for short-term occupancy, such as inns, hotels, motels, and tourist homes.

Modern rental occupants differ greatly with respect to the length of time they remain on the premises: some reside there permanently; some remain for extended periods while retaining permanent homes elsewhere; some stay only briefly while traveling. Occupants also differ in regard to the nature and number of the services they receive from the owner of the property. Some receive all conveniences ordinarily provided in hotels, such as maid and janitorial service, and assume no obligations as to the repair of their dwelling units. Others occupy their units completely independently of the owner, assume full responsibility for the care of the premises and their belongings contained therein, and provide for all necessary services themselves.

Courts have categorized rental occupants as tenants, lodgers, and guests. ${ }^{3}$

1. See N.Y. Murttple Dwelling Law ix-xxi. Sce also Mradfes v. Reverly Development Corporation, 251 N.Y. 12, 166 N.E. 787 (1929) (dissenting opinion).

For purposes of this discussion the word "rent" will be used to encempass any montey paid by an occupant to an owner for the use of the premises.

2. For example, a large development in New York City was designed to consist of tive 14-story buildings containing, in the aggregate, 2,095 apartments. N.Y. Times, May 27, 1951, §8, p. 6, col. 4. One apartment project in New York City covered 192 acres and accommodated 12,200 families. N.Y. Mivltiple Dwerlung Law ix.

These structures contain innumerable varietics of units. One apartment building, erected in New York City in 1951, contained units ranging from one and one-half to eight and one-half rooms. N.Y. Times, Alay 27, 1951, § 8, p. 6, col. 4.

3. See Roberts v. Casey, 36 Cal. App. 2d 767, 93 P.2d 654 (Super. Ct. 1939); Cedar Rapids Inv. Co. v. Commodore Hotel Co., 205 Iowa 736, 218 N.W. 510 (1928) ; 22 Afr:::. L. REv. 1055 (1938). For further discussion of these relationships, see 1 Azrefres: Law of Property § 3.7 (Casner ed. 1952); 1 Tiffany, Landzond and Tenalis 34 (1912); BEALE, INNKEEPERS $\$ \S 138,139,140,291$ (1906); 17 TEx. L. REv. 380 (1939).

Occupants may receive more specialized classification as "employecs" or "servants." However, these designations are beyond the purview of this analysis. For discussion of the employee-tenant distinction, see 20 WASH. L. REv. 169 (1945); 1 Asserran: LAw of Property \$ 3.8 (Casner ed. 1952).

Some courts have used "boarder" and "roomer" as a synonym for "lodger." See, e.g., City of Independence v. Richardson, 117 Kan. 656, 232 Pac. 1044 (1925); Pullman Palace 
Conversely, they have designated the owners or managers of rented property as landlords, lodginghouse keepers, and innkeepers. ${ }^{4}$ Since owners may have differing relationships with their various occupants, ${ }^{5}$ courts have focused primarily on the living conditions of the occupant of the rented premises in arriving at their categorizations.

\section{The "E.xclusiveness" and "Transiency" Tests}

In determining the status of an occupant as either tenant or lodger, courts have formulated the test of "exclusiveness" : ${ }^{6}$ the tenant is said to have exclusive possession of his quarters, ${ }^{7}$ while the lodger has merely a right to the use of the premises, the owner retaining control of and access to them. ${ }^{8}$ This test springs from the conceptual distinctions employed since the beginning of property law. For the relation of landlord and tenant to exist, there must be a grant of the exclusive possession of property for a specified term. ${ }^{0}$ Such a

Car Co. v. Lowe, 28 Neb. 239, 247, 44 N.W. 226, 228 (1899) ; Beall v. Everson, 34 A.2d 41 (D.C. Mun. Ct. App. 1943). In this Comment the term "lodger" will include both "boarders" and "roomers."

Parties may contract as to their status, and courts will enforce this instead of the relationship dictated by the factual pattern of accupancy. Sce Baldwin Piano Co. v. Congress Fotel Co., 243 IIl. App. 118 (1926).

4. See Alpaugh v. Wolverton, 184 Va. 943, 36 S.E.2d 906 (1946); 22 Minn. L. Riv. 1055 (1938).

"Lodginghouse keeper" will herein encompass "boardinghouse keeper." Further, while some of the cases use "landlord" to mean anyone owning or operating rented premises, landlord will here indicate the owner or manager of premises occupied by tenants. And an "innkeeper" includes hotel owners. Dixon v. Robbins, 246 N.Y. 169, 172, 158 N.E. 63 (192\%) (dictum); Appeal of Wellsboro Hotel Co., $336 \mathrm{~Pa} .171,174,7$ A.2d 334, 335 (1939) (same).

5. An owner may be simultaneously an innkeeper, lodginghouse keeper, and landlord as to his various occupants. Erwin v. City of San Diego, 112 Cal. App. 2d 213, 217, 246 P.2d 105, 108 (4th Dist. 1952) (dictum); Alpaugh v. Wolverton, 184 Va. 943, 948, 36 S.E.2d 906, 908 (1946) (same).

Some courts have held that the nature of the premises raises a rebuttable presumption as to the occupant's status. See, e.g., Fay v. Pacific Improvement Co., 93 Cal. 253, 26 Pac. 1099 (1892) (occupant presumed to have gone to "hotel" as a guest).

Even as to the same occupant, an owner may occupy one relationship for one purpose, as for statutory classification, and another with respect to a question such as tort liability. See, e.g., McClaugherty v. Cline, 128 Tenn. 605, 163 S.W. 801 (1913).

6. Taylor v. Dean, 78 A.2d 382 (D.C. Mun. Ct. App. 1951) ; Byrd v. Feilding, 238 S.W.2d 614 (Tex. Civ. App. 1951); 1 Amerucan Law of Property $\$ 3.7$ (Casner cd. 1952); 17 TEX. L. Rev. 380 (1939) and cases there cited; 22 MINN. L. Rev. 1055 (1938) and cases there cited.

7. Coggins v. Gregorio, 97 F.2d 948 (10th Cir. 1938); Marden v. Radford, 229 Mo. App. 789, 84 S.W.2d 947 (1935); Linwood Park Co. v. Van Dusen, 63 Ohio St. 183, 58 N.E. $576(1900)$.

8. Beall v. Everson, 34 A.2d 41 (D.C. Mun. Ct. App. 1943) ; Carroll v. Cooncy, 116 Conn. 112, 163 Atl. 599 (1933); White v. Maynard, 111 Mass. 250, 15 Am. Rep. 28 (1872).

9. Woodfali, Landlord and Tenant 2 (24th ed., Blundell, 1939); Fon, Outline of The Law of Landlord and Tenant 17 (1928); Gear, a Treatise of The Law of LANDLORD AND TENANT 136 (1888). 
grant is considered a lease ${ }^{10}$ and gives the tenant an "interest in land."11 If the owner does not transfer exclusive possession to the occupant, the occupant is termed a lodger and holds property only under a license. ${ }^{12}$

The occupant has exclusive possession only if the owner has not retained a right to enter the premises during occupancy. ${ }^{13}$ Courts have considered a variety of factors as indicating that the occupant was not entitled to exclusive possession or that the owner intruded upon it: the owner lived in the same building as the occupant ;14 the owner retained a key to the occupant's rooms ;5 the owner was charged with cleaning hallways and windows $;^{10}$ the owner had the right to enter the premises to make repairs; ${ }^{17}$ the occupant shared a bath

The exclusiveness test achieved its modern form from the construction of certain nineteenth century English statutes. Each of these statutes required the courts to distinguish between various types of occupants. See Ancketill v. Baylis, 10 Q.B.D. 577 (18S2) (lodgcr and tenant had different voting rights under a voting statute); Kent v. Fittall, [1906] 1 K.B. 60 (same) ; Ness v. Stephenson, 9 Q.B.D. 245 (18\$2) (statute exempting "lodgers" from distraint for rent) ; Reg. v. Assessment Committee of St. George's Union, L.R. 7 Q.B. 90 (1871) (taxing statute).

10. In re Ow1 Drug Co., 12 F. Supp. 439 (D. Nev. 1935) ; Kaiser Co. v. Reid, 30 Cal. 2d 610, 184 P.2d 879 (1947) ; Roberts v. Lynn Ice Co., 187 Mass. 402, 73 N.E. 523 (1905).

11. McDowell v. Hyman, $117 \mathrm{Cal}$ 67, 48 Pac. 984 (1897); Beck v. Bechtel Hotels, Inc., 72 A.2d 36 (D.C. Mun. Ct. App. 1950) ; Mallam v. Trans-Texas Airways, 227 S.IV.2d 344 (Tex. Civ. App. 1949).

12. Tips v. United States, 70 F.2d 525 (5th Cir. 1934); People v. Vaughan, 65 Cal. App. 2d Supp. 844, 150 P.2d 964 (1944); Roberts v. Lynn Ice Co., 187 Mass. 402, 73 N.E. 523 (1905) ; 1 McAdasr, Landiond and TeNaxt 239 (5th ed. 1934); III Kest's CoMmentaries 452 n.l (b) (14th ed. 1896).

13. It is unclear whether an unexercised right of entry is enough to breach exclusive possession or whether actual entry is necessary, since most cases involve an actual entry by the owner, making the occupant a lodger under either standard. See, c.g., Fox v. Windemere Hotel Apartment Co., 30 Cal. App. 162, 157 Pac. \$20 (1st Dist. 1916) ; Carroll v. Cooney, 116 Conn. 112, 163 Atl. 599 (1933) ; Peaks v. Cobb, 197 Mass. 554, 83 N.E. 1106 (1908). One case, however, specifically states that right of entry alone is sufficient. See Marden v. Radford, 229 Mí. App. 789, 84 S.W.2d 947 (1935). See also Dewar v. Minneapolis Lodge No. 44, B. \& P.O.E., 155 Minn. 98, 192 N.WY. 358 (1923) (occupant held lodger because owner exercised "general control and supervision" of the premises).

A few courts have held that even though there has been an actual entry, the occupant may still be a tenant. See MIartin v. Shryock Realty Co., 236 MIo. App. 1265, 163 S.IV.2d 804 (1942) (occupant held tenant since services provided by owner could be waived; thus no one had right to enter apartment without consent of occupants); Shearman v. Iriquois Hotel and Apartment Co., 42 Misc. 217, 85 N.Y. Supp. 365 (Sup. Ct. 1903) (occupant held tenant since services provided by owner did not interfere with or limit tenant's right of use and occupation).

14. Carroll v. Cooney, 116 Conn. 112, 115, 163 Atl. 599, 600 (1933) ; Byrd v. Fcilding, 238 S.W.2d 614, 616 (Tex. Civ. App. 1951).

15. Erwin v. City of San Diego, 112 Cal. App. 2d 213, 246 P.2d 105 (4th Dist. 1952); Lambert v. Sine, 256 P.2d 241 (Utah 1953).

16. Roberts v. Casey, 36 Cal. App. 2d 767, 93 P.2d 654 (Super. Ct. 1939) ; Marden v. Radford, 229 Mo. App. 789, 84 S.W.2d 947 (1935).

17. Fox v. Windemere Hotel Apartment Co., 30 Cal. App. 162, 157 Pac. $\$ 20$ (1st Dist. 1916); Simmons v. Weinsoff, 58 A.2d 497 (D.C. Mun. Ct. App. 1948); Byrd v. Feilding, 238 S.W.2d 614 (Tex. Civ. App. 1951). 
or kitchen with the owner $; ;^{18}$ the premises were furnished $; 10$ maid service was provided $;^{20}$ towels and linens were supplied; ${ }^{21}$ light, heat, and water were provided. ${ }^{22}$ In cases establishing some or all of the above factors, the occupant has normally been held to be a lodger. ${ }^{23}$

Courts have devised the test of "transiency" to distinguish between the lodger and the guest. ${ }^{24}$ The guest is one who stays at a place for an uncertain but temporary period while traveling ; $;^{25}$ a lodger stays for a longer and more definite period ${ }^{26}$ and makes the premises his present home. ${ }^{27}$ The transiency test evolved from conditions existing in early England. Since traveling was

18. Roberts v. Casey, 36 Cal. App. 2d 767, 93 P.2d 654 (Super. Ct. 1939) ; Taylor v. Dean, 78 A.2d 382 (D.C. Mun. Ct. App. 1951).

19. Carroll v. Cooney, 116 Conn. 112, 163 Atl. 599 (1933) ; Mathews v. Livingston, 86 Conn. 263, 85 Atl. 529 (1912).

20. Tamamian v. Gabbard, 55 A.2d 513 (D.C. Mun. Ct. App. 1947); Martin v. Shryock Realty Co., 236 Mo. App. 1265, 163 S.W.2d 804 (1942).

21. Lindsey v. Watson, 83 A.2d 226 (D.C. Mun. Ct. App. 1951) ; Messerly v. Mercer, 45 Mo. App. 327 (1891) ; Lambert v. Sine, 256 P.2d 241 (Utah 1953).

22. Lambert v. Sine, 256 P.2d 241 (Utah 1953); Marden v. Radford, 229 Mo. App. 789, 84 S.W.2d 947 (1935).

23. See, e.g., Roberts v. Casey, 36 Cal. App. 2d 767, 93 P.2d 654 (Super. Ct. 1939) ; Taylor v. Dean, 78 A.2d 382 (D.C. Mun. Ct. App. 1951); Marden v. Radford, 229 Mo. App. 789, 84 S.W.2d 947 (1935) ; Mallam v. Trans-Texas Airways, 227 S.W.2d 344 (Tex. Civ. App. 1949). Conversely, when these facts are not established, the courts are likcly to find a landlord-tenant relationship. See, e.g., Coggins v. Gregorio, 97 F.2d 948 (10th Cir. 1938); Mathews v. Livingston, 86 Conn. 263, 85 Atl. 529 (1912); Green v. Shocmaker, 111 Md. 69, 73 Atl. 688 (1909).

24. Burdock v. Chicago Hotel Co., 172 Ill. App. 185 (1912); Hart v. Mills Hotcl Trust, 144 Misc. 121, 258 N.Y. Supp. 417 (N.Y. Munic. Ct. 1932); Meacham v. Galloway, 102 Tenn. 415, 52 S.W. 859 (1899); 14 R.C.L. 496 (1916) and cases there collected; 22 MINN. L. REv. 1055 (1938).

25. Petit v. Thomas, 103 Ark. 593, 148 S.W. 501 (1912); Shoecraft v. Bailey, 25 Iowa 553 (1868) ; Holstein v. Phillips \& Sims, 146 N.C. 366, 59 S.E. 1037 (1907); 22 MINN. L. Rev. 1055 (1938).

26. In most cases where the occupant is held to be a lodger, there is some sort of contractual agreement between the owner and the occupant either as to rate or length of stay. See, e.g., Clifford v. Stafford, 145 Ill. App. 247 (1908); Goodyear Tire \& Rubber Co. v. Altamont Springs Hotel Co., 206 Ky. 494, 267 S.W. 555 (1925); Asseltyne v. Fay Hotel, 222 Minn. 91, 23 N.W.2d 357 (1946); Smith v. Dorchester Hotel Co., 145 Wash. 344, 259 Pac. 1085 (1927).

Normally, mere length of stay does not convert a guest into a lodger. Moon v. Yarian, 147 Ill. App. 383 (1909); Ross v. Mellin, 36 Minn. 421, 32 N.W. 172 (1887); Leon v. Kitchen Bros. Hotel Co., 134 Neb. 137, 277 N.W. 823 (1938). But cf. Crapo v. Rockwell, 48 Misc. 1, 94 N.Y. Supp. 1122 (Sup. Ct. 1905). However, some occupants have been held lodgers without a special agreement as to length of stay when they have remained on the premises for extended periods of time paying a weekly or monthly rate. See, e.g., Gray v. Drexel Arms Hotel, 146 Ill. App. 604 (1909) ; McIntosh v. Schops, 92 Ore. 307, 180 Pac. 593 (1919).

27. Marden v. Radford, 229 Mo. App. 789, 799, 84 S.W.2d 947, 954 (1935) (dictum); McIntosh v. Schops, 92 Ore. 307, 309, 180 Pac. 593 (1919) (same).

The origin of the distinction between the lodger and the guest is Calye's case, [1584] 8 Co. Rep. 32a, 77 Eng. Rep. 520 (a "neighbor ... is no traveller"), and an accompanying 
slow and hazardous, ${ }^{28}$ travelers were limited in their choice of accommodations. ${ }^{29}$ Innkeepers with available rooms were therefore placed under the duty of accepting any person requesting accommodations, ${ }^{30}$ and strict safeguards were provided for the protection of both parties. ${ }^{31}$ In contrast, lodgers were persons who usually lived for longer periods of time in private homes in close association with the owners. ${ }^{32}$ For this reason they had both the aim and the opportunity of selecting suitable quarters. Lodginghouse keepers were given a corresponding right to select those whom they desired to occupy their premises.33 Since each party had the chance to assess the character of the other, fewer mutual protections were given them by the courts. ${ }^{34}$

Although the transiency test is widely applied, ${ }^{35}$ confusion has developed concerning the factors distinguishing the transient from the non-transient. One

note, ibid. ("If a man hires a chamber for a tern . . . the innkeeper is not chargeable") (emphasis added). However, the distinction did not become well recognized until the 17th century. See Daniel v. Hotel Pacific Pty., Ltd., [1953] Argus Law Rep. 1043.

28. Transients during these times were, of course, subject to many dangers, not the least of which was the threat of robbery by highwaymen or bandits. Sce Crapo v. Rocl:well, 48 Misc. 1, 94 N.Y. Supp. 1122 (Sup. Ct. 1905); Beale, Imrnekpens $\$ \$ 1-6$ (1906).

29. Inns developed for the entertainment of travelers while on their journeys. See Odom v. East Avenue Corp., 178 Misc. 363, 34 N.Y.S.2d 312 (Sup. Ct. 1942) ; Sawdey Liquor License Case, $369 \mathrm{~Pa} .19,85$ A.2d 28 (1951); II KeNr's Cossurentanirs 590 (14th ed. 1896). However, the traveler could never be sure of the character of the innlseper or his servants, and frequently inns wcre very unsafe. See Crapo v. Rockwell, 48 Mfise. 1, 94 N.Y. Supp. 1122 (Sup. Ct. 1905); Hulett v. Swift, 33 N.Y. 571 (1865); Micintosh v. Schopps, 92 Ore. 307, 180 Pac. 593 (1919); BeALE, InNKeEpers \$ 331 (1900).

30. Petit v. Thomas, 103 Ark. 593, 148 S.T. 501 (1912); Nelson v. Johnson, 104 Minn. 440, 116 N.W. 828 (1908) ; Roberts v. Case Hotel Co., 106 Mrise. 481, 175 N.Y. Supp. 123 (Sup. Ct. 1919). The only limitations on this rule were that the applicant present himself in a receivable condition and pay the going rate. Thompson v. Lacy, [1820] 3 B. \& Ald. 283, 287, 105 Eng. Rep. 667, 668 (dictum). See also Petit v. Thomas, 103 Arls. 593, 598, 148 S.W. 501, 503 (1912) (same); 23 TExAS L. REv. 289 (1945).

31. Since the transient was compelled to place implicit trust in the innlseepers and his employees, strict duties were imposed on the innkeeper, such as his absolute duty to protect the goods of his guests. See II Kent's Cosrarentruares 594 (14th ed. 1890); Beale v. Posey, 72 Ala. 323 (1882) ; Hulett v. Swift, 33 N.Y. 571 (1865). Since the innkeeper likewise had no opportunity to assess the character of his guests, he was given a countervailing protection against overdue rents in the innkeeper's lien. See Roberts y. Case Hotel Co., 106 Misc. 481, 175 N.Y. Supp. 123 (Sup. Ct. 1919).

32. The early English cases defining a lodger clearly contemplated a close personal relationship between occupant and owner. See, c.g., Ness v. Stephenson, 9 Q.B.D. 245, 252 (18S2) (quoting Lindley, L.J.: "A lodger denotes a personal relation of some one lodging somewhere with somebody.") ; Monks v. Dykes, [1839] + Mr. \& W. 567, 569, 150 Eng. Rep. 1546, 1547; Woodfali, Landorord and Tenant 10 (24th ed., Blundell, 1939). See also 1 American Law of Property \$ 3.7 (Casner ed. 1952).

33. For modern recognition of this right, see Birmingham Railway, Light \& Power Co. v. Drennen, 175 Ala. 338, 355, 57 So. 876,882 (1911) (dictum); Huntley v. Stanchfield, 168 Wis. $119,123,169$ N.W. 276, 277 (1918) (same).

34. For example, a lodginghouse keeper is not an insurer of the goods of a ludger, but is liable only upon a showing of negligence. See note 49 infro. Conversely, the lodginghouse keeper had no common law lien for unpaid rent. See note 65 infra.

35. See, e.g., Cottmire v. 181 East Lake Shore Drive Hotel Corp., 330 IIl. App. 54y, 
line of decisions has held that where a contract exists between owner and occupant regarding price and/or length of stay, it constitutes conclusive proof that the occupant is not a transient and therefore is not a guest.. ${ }^{30}$ Another group of cases has regarded this "special contract" merely as evidence of lodger status. ${ }^{37}$ These courts have emphasized a variety of additional facts in distinguishing the guest from the lodger: whether the dwelling unit was in a hotel rather than a private home; $;^{38}$ whether the occupant had another home: ${ }^{30}$ whether the occupant received the same treatment as short-term guests..$^{10} \mathrm{De}$ cisions have sometimes turned on the presence or absence of only one such factor. ${ }^{41}$

\section{Consequences of Categorization}

A court's classification of a particular occupant as tenant, lodger, or guest is almost always determinative of the legal rights and duties of both the occupant and the owner. The consequences resulting from classification may conveniently be summarized in connection with three general types of actions involving owners and occupants of rented premises.

The tenant is accorded different treatment from the lodger and guest in cases involving the use and enjoyment of rented premises, because only the tenant has an interest in land. ${ }^{42}$ Thus only a tenant may maintain possessory actions, such as actions for ejectment, trespass, or nuisance. ${ }^{43}$ Notice to quit is required to terminate the possession of a tenant, but not the possession of a

71 N.E.2d 823 (1947) ; Layton v. Seward Corp., 320 Mich. 418, 31 N.W.2d 678 (1948); Asseltyne v. Fay Hotel, 222 Minn. 91, 23 N.W.2d 357 (1946).

36. See, e.g., Clifford v. Stafford, 145 Ill. App. 247 (1908); Goodyear Tire and Rubber Co. v. Altamont Springs Hotel Co., $206 \mathrm{Ky} .494,267$ S.W. 555 (1924); Neal v. Wilcox, 49 N.C. 146, 67 Am. Dec. 266 (1856). See also Daniel v. Hotel Pacific Pty., Ltd., [1953] Argus L. Rep. 1043.

In the absence of a special contract, courts have examined other factors to determine whether the occupant was a lodger or guest. See cases cited note 26 sthpra.

37. See, e.g., Cottmire v. 181 East Lake Shore Drive Hotel Corp., 330 IIl. App. 549, 71 N.E.2d 823 (1947) ; Ross v. Mellin, 36 Minn. 421, 32 N.W. 172 (1887); Leon v. Kitchen Bros. Hotel Co., 134 Neb. 137, 277 N.W. 823 (1938); Hancock v. Rand, 94 N.Y. 1, 46 Am. Rep. 112 (1883) ; Smith v. Dorchester Hotel Co., 145 Wash. 344, 259 Pac. 1085 (1927).

38. See Fay v. Pacific Improvement Co., 93 Cal. 253, 26 Pac. 1099 (1891); Layton v. Seward Corp., 320 Mich. 418, 31 N.W.2d 678 (1948).

39. Ross v. Mellin, 36 Minn. 421, 32 N.W. 172 (1887) ; Smith v. Dorchester Hotel Co., 145 Wash. 344, 259 Pac. 1085 (1927); Jalie v. Cardinal, 35 Wis. 118 (1874). See also Lusk v. Belote, 22 Minn. 468 (1876) (occupants held lodgers because they were residents of the city in which the hotel was located).

40. Cottmire v. 181 East Lake Shore Drive Hotel Corp., 330 Ill. App. 549,71 N.E.2d 823 (1947); Leon v. Kitchen Bros. Hotel Co., 134 Neb. 137, 277 N.W. 823 (1938).

41. See, e.g., Gray v. Drexel Arms Hotel, 146 IIl. App. 604 (1909) (occupant had no other abode); Leon v. Kitchen Bros. Hotel Co., 134 Neb. 137, 277 N.W. 823 (1938) (occupant received same treatment as other transients).

42. See note 11 supra.

43. See Mathews v. Livingston, 86 Conn. 263, 267, 85 At1. 529, 531 (1912) (dictum) 
lodger or guest. 44 If a tenant leaves the premises in violation of an agreement, the landlord may bring an action for rent; 45 if a lodger or guest leaves, the owner is confined to a suit for breach of contract, with the resulting duty to mitigate damages. ${ }^{46}$ A lease is within the Statute of Frauds, in contrast to an agreement for lodgings. ${ }^{47}$ And a covenant in a lease prohibiting subletting is not violated if the tenant turns the premises over to a lodger.48

The category of the occupant also determines who bears the responsibility for protecting the occupant's property. Lodgers and tenants have the duty to

(ejectment and trespass); Roberts v. Casey, 36 Cal. App. 2d 767, 771, 93 P.2d 654, 657 (Super. Ct. 1939) (same); 1 Tiffany, Landond and Tenant 34 (1912).

It has long been the rule that only one who has an "interest in land" may bring a suit for damage to that land caused by a nuisance. See generally, Hosmer v. Republic Steel \& Iron Co., 179 Ala. 415, 60 So. S01 (1913); Klassen v. Central Kansas Couperative Creamery Ass'n, $160 \mathrm{Kan} .697,165$ P.2d 601 (1946). Thus some courts felt that even in suits for personal injuries due to nuisance an interest in land had to be shown. See Broderick v. City of Waterbury, 130 Conn. 601, 36 A.2d 585 (1944); Kavanagh v. Barber, 131 N.Y. 211, 30 N.E. 235 (1S92). However, most courts in personal injury actions have allowed anyone lawfully occupying the premises to recover. See Klassen v. Centeral Kansas Cooperative Creamery Ass'n, 160 Kan. 697, 165 P.2d 601 (1946); United Electric Light Co. v. The Deliso Construction Co., 315 Mass. 313, 52 N.E.2d 553 (1943) ; Hodges v. Town of Drew, 172 Miss. 668, 159 So. 298 (1935).

44. Hundley v. Milner Hotel Management Co., Inc, 114 F. Supp. 206 (W.D. Ky. 1953) (occupant held tenant-notice necessary); Dewar v. Arinneapolis Lodge, No. 44, B. \& P.O.E., 155 Minn. 98, 192 N.W. 358 (1923) (occupant held lodger-notice unnecessary) ; Tamamian v. Gabbard, 55 A.2d 513 (D.C. Mun. Ct. App. 1947) (occurant held lodger-notice unnecessary); 1 Aarericax LaW of Property § 3.7 (Casner ed. 1952).

At common law, the length of the rental period usually determined the amount of notice required. See $i d$. at $\$ 3.90$. Amount of notice is now generally covercd by statute, and in many instances the common law rules have been changed. Though some state statutes have been interpreted to require notice only by the lessor, generally both parties must give notice. Ibid. See id. at 375 n.6 for examples of typical statutes.

45. Heckel v. Griese, 12 N.J. Míisc. 211, 171 Atl. 14S (1934); Sancourt Realty Corp. v. Dowling, 220 App. Div. 660, 222 N.Y. Supp. 288 (Sup. Ct. 1927). The advantage of being able to label the action as one under a lease for "rent" is that in many jurisdictions the lessor is under no duty to minimize his damages upon abandonment by the tenant. He may leave the premises vacant and sue for the rent as it becomes due. $A$ minority of courts require the lessor to exercise reasonable diligence in attempting to relet the premises. See cases collected in Comment, 64 Y YLE L.J. 85, 119 nn.203-05 (1954); Annot., 126 A.L.R. 1219 (1940). If, however, the action is one for simple breach of contract, there is always the duty to mitigate. See note 46 infra.

46. Ashton v. Margolies, 72 Misc. 70, 129 N.Y. Supp. 617 (Sup. Ct. 1911); Wilson v. Martin, 1 Denio 602 (N.Y. 1S45); Mallan v. Trans-Texas Airways, 227 S.W.2d 344 (Tex. Civ. App. 1949).

47. White v. Maynard, 111 Mass. 250 (1872); Wright v. Stavert, [1860] 2 El. \& El. 721, 121 Eng. Rep. 270; 1 Amrerican Law of Property $\$ 3.7$ (Casner ed. 1952). But sce Wilson v. Martin, 1 Denio 602 (N.Y. 1845).

48. Beall v. Everson, 34 A.2d 41 (Mun. Ct. App. D.C. 1943); Ross v. Haner, 244 S.W. 231 (Tex. Civ. App. 1922); Peaks v. Cobb, 197 Mass. 554, 83 N.E. 1105 (1908) (contract not to "lease, underlet, nor permit any other person ... to occupy or improve" the premises not violated by rental to a lodger); Wise v. Vaughner, 105 N.Y.S.2d 333 (N.Y. Ifunic. Ct. 1951). But cf. Washington Realty Co. v. Harding, 45 A.2d 785 (D.C. 
care for their own belongings, and the owner is liable for loss of their goods only upon proof of negligence. ${ }^{49}$ However, the innkeeper is held to a higher degree of responsibility for the goods of his guests. Statutes in most states have limited the common law liability of the innkeeper for non-negligent ${ }^{\text {to }}$ loss of valuables if he maintains a safe and posts proper notice. ${ }^{61}$ Yet the innkeeper retains his common law duty as insurer ${ }^{52}$ if he fails to comply strictly with the statutory requirements, ${ }^{63}$ or if the lost goods are not covered by the statute.

In addition, varying consequences follow with respect to personal injuries suffered by different type occupants as a result of defects on the premises. An innkeeper impliedly warrants that the rooms he rents are fit for immediate

Mun. Ct. App. 1946). It is a logical, though unlitigated, assumption that a "no sublease" clause would not be breached on suboccupancy by a guest.

It is possible for the owner to waive a "no sublease" clause by failure to object upon knowledge of the suboccupant's presence. See Farose Realty Corp. v. Shaff, 117 N.Y.S.2d 375 (N.Y. Munic. Ct. 1952).

One possible reason for the general rule is that sublease prohibitions are not favored and are therefore strictly construed against the owner. See Wise v. Vaughner, 105 N.Y.S.2d 338 (N.Y. Munic. Ct. 1951); 1 Thfrany, LandloRd and Tenant 921 (1912).

49. Haff v. Adams, 6 Ariz. 395, 59 Pac. 111 (1899) (lodginghouse keeper not liable); Asseltyne v. Fay Hotel, 222 Minn. 91, 23 N.W.2d 357 (1946) (same); Wells v. West, 212 N.C. 656, 194 S.E. 313 (1937) (same); Goodyear Tire and Rubber Co. v. Altamont Springs Hotel Co., $206 \mathrm{Ky} .494,267 \mathrm{~S} . W .555$ (1925) (lodginghouse keeper liable dute to negligence); BEALE, InNKEEPERS $\$ \$ 331,332$ (1906). Since a lodginghouse leeper is only liable upon a showing of negligence, it would seem to follow that proof of negligence would also be necessary to hold a landlord.

50. Most courts rule that even though the statute is complied with in all respects, the innkeeper is liable for the full amount of the loss if either he or his employees are negligent. Note, 57 DiCK. L. REv. 348 (1953) and cases there cited.

51. See generally, Beale, Innkeepers $\$ 411-32$; Note, 57 Dick. L. Rev. 348 (1953); which liability may be avoided, there are two basic types: those that expressly except from the protection of the statute goods needed in the guest's room; and those that expressly enumerate classes of goods that must be deposited with the owner in order to be protected, the innkeeper retaining his common law liability with respect to other property. See Note, 28 Mrcr. L. Rev. 345 (1930). For examples of typical statutes, see ArK. Stat. Ann. §71-1107 (1947) ; Conn. Gen. Stat. \$§ 6807-09 (1949); N.Y. Gen. Bus. LAW § 201 ; OتHO REv. CODE $\$ 4721.01-.03$ (1953). It is not uncommon to find in tho statutes a maximum innkeeper liability figure of $\$ 500$ or less. See, c.g., Arrz. Code ANN. $\S 62-304$ (Supp. 1952); CAL. CIv. Code \$ 1859 (1949).

52. A majority of American courts have held the innkeeper liable as an insurer of the goods of his guests. That is, he is liable unless the loss is caused by act of God, act of the public enemy or negligence of the guest. BEALE, INNKEEPERS $\$ 185$. In some jurisdictions the innkeeper is liable only if he or his servants have been negligent. Id. at $\$ \$ 186,187$. For a more recent collection of cases see, 28 AMr. JuR., Imkeepers $\$ 67$ (1940). For a general discussion of the innkeeper's liability, see 28 Mich. L. REv. 345 (1930).

In case of loss by accidental fire, the innkeeper is liable vel non depending on the rule adopted in the jurisdiction concerned. BEALE, op. cit. supra $\$ 189$ and cases there citcd. For more recent cases see 28 A.r. JUR., Innkeepers $\$ 106$ (1940). See 32 Iowa L. Rev. 95 (1944).

53. These statutes, being in derogation of the common law, are strictly construcd. Layton v. Seward, 320 Mich. 418, 31 N.W.2d 678 (1948); Kelly v. Milncr Hotels, 176 Pa. Super. 316, 106 A.2d 636 (1954). 
occupancy, ${ }^{54}$ while the general rule is that the landlord gives no such warranty in connection with leased premises.55 Furthermore, a landlord is under no duty to repair defects on the premises subsequent to the signing of the lease, ${ }^{60}$ except under statute ${ }^{57}$ or when the tenant's duty to repair is shifted by agreement between the parties.58 Therefore, the landlord is generally not liable for injuries to a tenant resulting from such defects. ${ }^{59} \mathrm{~A}$ lodginghouse keeper or innkeeper, however, is under a duty to exercise reasonable care to keep the premises in

54. Nettles v. Emerick, 22 F. Supp. 441 (MI.D. Pa. 1938); Hotel Richmond, Inc v. Wilkinson, 73 Ga. App. 36, 35 S.E.2d 536 (1945); Crockett v. Troyk, 78 S.W.2d 1012 (Tex. Civ. App. 1935).

55. 1 Amrerican Law of Property $\$ 3.45$ (Casner ed. 1952) and eases there cited. The tenant is the purchaser of an estate and is therefore subject to the doctrine of caveat emptor. Ibid. There is the so-called "furnished house" exception to this general rule Courts which follow this concept hold that if the lease provides for short-term occupancy of a furnished dwelling, there may be an implied warranty of fitness. See Young $v$ Povich, 121 Me. 141, 116 Atl. 26 (1922); Ingalls v. Hobbs, 156 MIass. 348, 31 N.E. 286 (1892); 1 Axrerican Law of Property $\$ 3.45$ (Casner ed. 1952). The justification for the rule is that if such premises are leased, immediate occupancy is doubtlessly intended and thus no opportunity of inspection is afforded the lessee Ibid.

It is unclear what, if any, warranty, is given by a lodginghouse kceper as to the fitness of his premises. On the one hard, it could be argued that, since a lodger is one who contracts specially with the owner and has some opportunity to inspect the premises, he should be subject to the same rules as a tenant. On the other hand, it would seem that the "furnished house" exception might well be applied to the typical lodger. Indeed, in Delamater v. Foreman, 1S4 MIinn. 428, 239 N.W. 148 (1931), 16 Minw. L. REv. 445, 17 IowA L. REv. 543 (1932), the court said that there was an implied covenant of fitness in the lease of an apartment, whether furnished or unfurnished, even though the term may not be short.

56. Coggins v. Gregorio, 97 F.2d 948 (10th Cir. 1938) and cases there cited; Zavalney v. Donovan, 70 Cal. App. 2d 182, 160 P.2d 558 (1st Dist. 1945); Haspen, Torms $\$ 103$ (1933); ProsSER, ToRTs 649-52 (1941). The landlord is liable for injuries resulting to the tenant from latent defects existing when possession is transferred if the landlord knew or should have known of their existence and had no reason to believe the tenant would discover them. Ibid.

57. Some statutes place the duty of repair on the owner. See, c.g., GA. Cone A:3:. $\$$ 61-111 (1935) ("The landlord must keep the premises in repair, and shall be liable for all substantial improvements placed upon them by his consent."); Mícr. Stars. Amz. $\$ 5.2843$ (1949) ; N.Y. Multiple Dwelling Law $\$ 78$ (owner required to keep premises in "good repair"). For general discussions of these statutes, see Harkrider, Tort Liability of A Landlord, 26 Mich. L. Rev. 383 (192S); 7 CORN. L.Q. 386 (1922).

58. Coggins v. Gregorio, 97 F.2d 948 (10th Cir. 1938) (dictum); Zavalney v. Donovan, $70 \mathrm{Cal}$. App. 2d 182, 1S4, 160 P.2d 558, 559 (1st Dist. 1945) (same). However, there is a split of authority as to the effect of such a contract. See 6 BarLos L. RE. $22 S$ (1954). Most courts say that where the owner breals the contract, the only remedy is an action for breach. However, an increasing minority hold the lessor liable in tort. Prosser, TORTS 658-61 (1941). If the owner undertakes to make certain sepairs and does so negligently, he is liable for any resulting injuries. Id. at 661 .

59. Dellangelo v. Home Owner's Loan Corp., 49 F. Supp. 71 (S.D.N.Y. 1943); Lusco v. Jackson, 27 Ala. App. 531, 175 So. 566 (1937); Rowland v. St. Alary's Bant, 93 N.H. 246, 40 A.2d 741 (1944). 
repair during occupancy, ${ }^{\infty 0}$ and retains a right of entry to the premises for this purpose. ${ }^{61}$ Therefore he may be liable for such injuries as are sustained on the premises by a lodger or guest. ${ }^{62}$ The same rules apply in actions by the occupant to recover sums expended for repairing defects as in actions to recover for injuries suffered as a result of the defects. ${ }^{03}$ Contributory negligence of the occupant is a defense in actions by the occupant both for loss of goods and personal injuries, regardless of the duty assumed by the owner. ${ }^{64}$

Judicial categorization as tenant, lodger, or guest may also result in procedural difficulties. Under statutes in many states, the landlord, lodginghouse keeper, and innkeeper are all given liens on the property of their occupants for unpaid rent. ${ }^{65}$ But delay and inconvenience may result if a strict court, by

60. Dye-Washburn Hotel Co. v. Aldridge, 207 Ala. 471, 93 So. 512 (1922) (innkeeper charged with duty to repair); Lonnecker v. Borris, 360 Mo. 529,229 S.W.2d 524 (1950) (lodginghouse keeper charged with duty to repair); Marden v. Radford, 229 Mo. App. 789, 84 S.W.2d 947 (1935) (same). 1 American LAW of Property \& 3.7 (Casner ed. 1952).

61. See Vaughn v. Neal, 60 A.2d 234 (D.C. Mun. Ct. App. 1948); Marden v. Radford, 229 Mo. App. 789, 84 S.W.2d 947 (1935) ; Jones v. Shannon, 55 Mont. 225, 175 Pac. 882 (1918).

62. McCleod v. Nel-Co Corp., 350 I11. App. 216, 112 N.E.2d 501 (1953) (innkecper held liable for injuries sustained from falling plaster); Parsons v. Dwightstate Co., 301 Mass. 324, 17 N.E.2d 197 (1938) (innkeeper held liable for defective shower valve); Nelson v. Ritz-Carlton Restaurant \& Hotel Co., 9 N.J. Misc. 1240, 157 Atl. 133 (1931) (innkeeper held liable for injuries to occupant sustained as a result of stepping on a needle on the floor of the room); Marden v. Radford, 229 Mo. App. 789, 84 S.W.2d 947 (1935) (lodginghouse keeper held liable for defective drainboard in kitchen).

63. If the lessor has covenanted to make repairs, the tenant may make such repairs if necessary and sue the owner for the cost. 1 AMrericaN LAw of Property $\$ 3.79$ (Caisner ed. 1952). It would seem to follow logically that, since a lodginghouse keeper and innkeeper are under a duty to repair even without a covenant, a lodger or guest would have a right of action for reimbursement of any money expended for repairs.

64. Corrigan v. San Marcos Hotel Co., 182 F.2d 719 (9th Cir. 1950) (guest barred in action for lost belongings); Shiman Bros. \& Co. v. Nebraska National Hotel Co., 146 Neb. 47, 18 N.W.2d 551 (1945) (same); Driskill Hotel Co. v. Anderson, 19 S.W.2d 210 (Tex. Civ. App. 1929) (same).

St. Paul Hotel Co. v. Lohm, 196 F.2d 233 (8th Cir. 1952) (guest barred in action for personal injuries); Duncan v. Chelsea Hotel Co., 326 Ill. App. 241, 61 N.E.2d 769 (19.15) (same); Morris v. Farnsworth Motel, 259 P.2d 297 (Utah 1953) (same).

Zavalney v. Donovan, 70 Cal. App. 2d 182, 160 P.2d 558 (1st Dist. 1945) (tenant barred in action for personal injuries); Turner v. Long, 61 Ga. App. 785, 7 S.E.2d 595 (1940) (same) ; Elson v. Renoclaf Realty Corp., 248 App. Div. 212, 290 N.Y. Supp. 644 (Sup. Ct. 1936) (same).

Also see note 52 supra.

65. See, e.g., ConN. Gen. Stat. \$§ 7247, 7248 (1949) (innkecper and lodginghouse keeper); CAL. Crv. CODE $\S 1861$ (1949) (hotel, motel, inn, boardinghouse, and lodging. house keepers) ; Ill. REv. Stat. c. $82, \S 57$ (1953). At common law, although the innkeeper had a lien on the goods of a guest, the lodginghouse keeper had no such lien. BEALE, INNKEEPERS $\S 252$, p. 176 n.3 (1906). Though the landlord had no common law lien, he did have the right to seize the tenant's goods for overdue rent in an action of distress. Wilson v. Martin, 1 Denio 602 (N.Y. 1845). Due to the harshness of this remedy, many states have either modified it considerably or completely abandoned it in 
categorization of the occupant, finds that the owner has proceeded under the wrong lien statute. ${ }^{66}$ Moreover, lodgers or guests may be evicted by the owner for good cause without resort to legal process. ${ }^{67}$ However, tenants may only be evicted by resort to an action of ejectment or prescribed statutory procedures. ${ }^{68}$ Thus a landlord may find himself liable in damages if he mistalienly pursues some other means of eviction. ${ }^{69}$ The categorizations are also important with respect to various state statutes and municipal regulatory and zoning ordinances, which grant certain rights and privileges only to specified classes of occupants and owners. ${ }^{70}$

\section{Use and Enjoyment of the Rented Premises}

The greater protection given to some occupants in cases involving the use and enjoyment of rented premises ${ }^{71}$ seems justifiable only if based on a theory of residence. Notice to quit, for example, provides the occupant with sufficient opportunity to find other accommodations. ${ }^{2}$ Such notice is necessary only

favor of some form of statutory lien. 1 Axrerican Law of Property $\$ 3.72$ (Casner ed. 1952) ; 2 id. $\$ 9.47$.

66. Such a situation seems analogous to that which existed before certain types of owners were given liens. See, e.g., Mathews v. Livingston, 86 Conn. 263, 85 Att. 529 (1912) ("landlord" not entitled to statutory lien given "lodginghouse keeper"); Brin v. Sidenstucker, 232 Iowa 1258, 8 N.W.2d 423 (1943) ("landlord" not entitled to lien given "innkeepers") ; Harden v. State, 47 Tex. Cr. Rep. 493, S4 S.W. 591 (1905) ("lodginghouse keeper" not entitled to lien given "boardinghouse keeper").

67. Raider v. Dixie Inn, 198 Ky. 152, 248 S.W. 229 (1923); Jacob v. Jacob, 125 Mfisc. $649,650,212$ N.Y. Supp. 62, 64 (City Ct. 1925) (dictum); McBride v. Hosey, 197 S.W.2d 372 (Tex. Civ. App. 1946). In evicting the occupant, the owner may use as much furce as is necessary under the circumstances. Neely v. Lott Hotels Co., 334 III. App. 91, 78 N.E.2d 659 (1948). See also Perrine v. Paulos, 100 Cal. App. 2d 655, 224 P.2d 41 (1950) (innkeeper liable in damages since good cause not shown).

68. For a general discussion of these statutes, passed as an alternative to the cumbersome action of ejectment, see 32 Axr. JuR, Landlord and Tenant $\$ 1016$ (1941). The ouner usually must show good cause and prove the existence of a landlord-tenant relationship. Ibid. But see Roberts v. Casey, 36 Cal. App. 2d 767, 93 P.2d 654 (Super. Ct. 1939) (unlawful detainer statute interpreted so as to allow suit against lodger as well as tenant).

69. Lambert v. Sine, 256 P.2d 241 (Utah 1953) (Held: occupant a "tenant" and therefore allowed to recover damages for owner's failure to resort to unlawiul detainer statute).

70. City of Independence v. Richardson, 117 Kan. 656, 232 Pac. 1044 (1925) ("rooming house" not covered by taxing regulations governing infer alio, "boarding houses," "hotels," "taverns," and "inns") ; Von Der Heide v. Zoning Board of Appeals, 204 MFisc. 746, 123 N.Y.S.2d 726 (Sup. Ct.), aff'd, 282 App. Div. 1076, 126 N.Y.S.2d 852 (2d Dep't 1953) (motel not within prohibition against building of 'inns" in certain area).

Other consequences sometimes arise from the tenant-lodger-guest distinctions. Sce, e.g., Birmingham Railway, Light \& Power Co. v. Drennen, 175 Ala. 338, 57 So. 876 (1911) (lodger could not serve as juror in case involving owner of premises); Sloan 1. Court Hotel, 72 Cal. App. 2d 30S, 164 P.2d 516 (1945) (status determined whether change of venue would be granted).

71. See text at note 42 supra.

72. See generally, Hundley v. Milner Hotel Management Co., 114 F. Supp. 20 (IV.D. 
for the occupant who is residing on the premises either permanently or for the forseeable future; the transient can move more quickly and need not be so particular about substitute accommodations for the remainder of a temporary stay. Similarly, the right to bring an action of ejectment or nuisance is granted to an occupant whose permanent residence on the premises has been severed or disturbed. ${ }^{73}$ The transient, however, has but a passing interest in the tuse of the premises and has relatively free access to other temporary quarters; therefore less reason exists to allow him to bring these actions. Finally, the purpose of a clause which prohibits subletting is presumably to prevent an occupant from taking up long-term residence on the premises without the prior approval of the owner. The owner has much less reason to object if the tenant's rooms are used briefly by a transient.

Yet the theory used by courts to grant greater protection to the tenant than to the lodger or guest is that only the tenant has an "interest in land."74 And they have reasoned that only by exclusive possession of the premises can an occupant have the interest in land required for protection as a tenant. ${ }^{75}$ Thus, in deciding use and enjoyment cases, courts have generally considered only those facts relating to exclusiveness and have largely ignored facts relating to the occupant's permanency of residence.

In holding an occupant to be a lodger and therefore not entitled to notice to quit, courts have considered the following facts significant: the premises were furnished ${ }^{70}$ the owner provided towels and linens, ${ }^{77}$ fuel and water, ${ }^{78}$ and maid service $;^{70}$ the owner had access to or exercised "general supervision and control" over the occupant's rooms. ${ }^{80}$ The emphasis given these factors, all of which are irrelevant in determining residence, has resulted in judicial denial of notice to quit to occupants who were paying rent at monthly intervals and who had resided on the premises for periods ranging from several months to

Ky. 1953) ; Graf v. Miller, 202 Misc. 887, 120 N.Y.S.2d 154 (Sup. Ct. 1952) ; Gladwell v. Holcomb, 60 Ohio St. 427, 54 N.E. 473 (1899); Chi-Okla Oil and Gas Co. v. Shertzer, 105 Okla. 111, 231 Pac. 877 (1924); 32 AM. JuR., Landlord and Tenant \$993 (1941).

73. See Auldridge v. Spraggin, 349 Mo. 858, 163 S.W.2d 1042 (1942) (ejcctment). It seems that permanency of residence is necessary to bring an action for nuisance for injuries to the property. However, an increasing number of jurisdictions permit even a short-term occupant to sue for personal injuries caused by a nuisance. See note 43 supra.

74. See note 11 supra.

75. Ibid.

76. Tamamian v. Gabbard, 55 A.2d 513 (D.C. Mun. Ct. App. 1947).

77. Ibid.; Messerly v. Mercer, 45 Mo. App. 327 (1891).

78. Ibid.

79. Neely v. Lott Hotels Co., 334 Ill. App. 91, 78 N.E.2d 659 (1948); Messerly v. Mercer, 45 Mo. App. 327 (1891).

80. Tamamian v. Gabbard, 55 A.2d 513 (D.C. Mun. Ct. App. 1947) ; Dewar v. Minneapolis Lodge No. 44, B. \& P.O.E., 155 Minn. 98, 192 N.W. 358 (1923).

In the recent case of Hundley v. Milner Hotel Management Co., 114 F. Supp. 206 (W. D. Ky. 1953), the court feit that the following facts, inter alia, indicated landlordtenant relationship: meals prepared in room and no maid service. 
several years. $^{81}$ These occupants seem to have been clearly prejudiced by eviction without notice.

Similarly, in construing clauses which prohibit subletting, ${ }^{82}$ courts, by utilizing the exclusiveness test, have often disregarded what would seem to be the clear intent of the lessor. ${ }^{83}$ They have considered the following facts as evidence that the occupant renting from the tenant was a lodger and that the tenant was therefore not in breach of the "no sublease" clause: the occupant rented furnished premises or a single room ; 84 the occupant shared bath and kitchen $;^{85}$ maid service was supplied $;^{86}$ the owner had a right of entry to repair. ${ }^{87}$ Since sublease prohibitions differ in wording, ${ }^{85}$ consideration should first be given to the construction of the particular clause. Where the clause prohibits only "subletting," the intent of the owner would seem to be defeated by the above approach, which has allowed occupants to reside on the premises without prior approval for periods as long as a year. ${ }^{83}$

81. See, e.g., Tamamian v. Gabbard, 55 A.2d 513 (D.C. Mun. Ct. App. 1947) (weelsly payments, occupancy for over a year); Neely v. Lott Hotels Co., 334 Ill. App. 91, 78 N.E.2d 659 (1948) (two and one-half years residence on the premises, payment intervals undetermined); Dewar v. Mrinneapolis Lodge No. 44, B. \& P.O.E., 155 AIinn. 98, 192 N.W. 358 (1923) (monthly payments, several months' residence).

82. Such clauses are strictly construed against the owner. See Wise v. Vaughner,

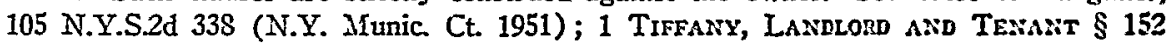
(1912) and cases there cited.

83. Consider, e.g., the holding in Peaks v. Cobb, 197 MIass. 554, 83 N.E. 1106 (1903), discussed in note 48 supra.

84. Application of Bierman, 274 App. Div. 1003, 84 N.Y.S.2d 355 (2d Dep't 1948) (single room); Farose Realty Corp. v. Shaff, 117 N.Y.S.2d 375 (N.Y. MIunic Ct. 1952) (furnished premises and single room).

85. Simmons v. Weinsoff, 58 A.2d 497 (D.C. Mun. Ct. App. 1948).

86. MIullins v. Nordlow, 170 Ky. 169, 185 S.W. 825 (1916); Peaks v. Cobbs, 197 Mass. 554,83 N.E. 1106 (1908). Mitlins is a classic example of a court sidestepping legal tchnicalities to reach a just result. The case was a damage action for injuries and deaths eaused by the burning of a hotel which, the court found, had no adequate fire eseapes. The owner argued that a "no sublease" clause had been breached and thus certain lodgers were trespassers and could not recover. The clause in question read: "The said proncrty" is to be used as hereinafter described and not otherwise, ziz., to be used as a family residesice; it being understcod that this prohibits the right to sublet any part of the premises for rooming purposes." Despite the "rooming purposes" phrase, the court held that the word "sublet" restricted the scope of the clause to situations wherein "tenants" were brought in under a sublease and thus the owner was held liable.

87. Simmons v. Weinsoff, 58 A.2d 497 (D.C. MIun. Ct. App. 1948).

In Beall v. Everson, 34 A.2d 41 (D.C. MIun. Ct. App. 1943), the court, finding that the parties had stipulated in the iower court that the occupants were "roomers," declined to consider any facts at all in holding that there was no breach of a sublease prohibition.

S8. Compare the clause in Peaks v. Cobb, 197 Mass. 554, 83 N.E. 1106 (1908), quoted in note 48 supra, with the one in Muilins v. Nordlow, $170 \mathrm{Ky}$. 169, $185 \mathrm{S.W}$. 825 (1916), quoted in note 86 sutra.

89. Simmons v. Weinsoff, 58 A.2d 497 (D.C. Miun. Ct. App. 1948) (over a year); Farose Realty Corporation v. Shaff, 117 N.Y.S.2d 375 (N.Y. MIunic Ct. 1952) (sis: months). 
Permanency of residence, however, has sometimes been considered in determining the occupant's right to bring certain types of possessory actions. For instance, an occupant was held a tenant, and therefore subject to eviction only by statutory procedures, because of his permanency of residence. ${ }^{90}$ And a longterm resident in a private home, sharing some facilities with the owner, was allowed to recover as a tenant for damages caused by a nuisance. ${ }^{01}$ Yet, in another case, permanent occupants paying at a monthly rate were held lodgers and denied the right to claim continued possession of premises sold following foreclosure, on the ground that they were not in exclusive possession since they shared certain facilities with the owner. ${ }^{82}$

The facts which should be of greatest weight in determining whether the occupant should receive notice to quit and whether he should have the right to bring possessory actions are those which relate to his permanency of residence on the premises: the length of his stay, the length of the rental period, and the presence or absence of another home. The same criteria should be applied to a suboccupant in determining whether the tenant is in breach of a "no sublease" clause. There are indications in recent years that the courts are becoming increasingly aware of the importance of these facts. ${ }^{03}$

90. In Lambert v. Sine, 256 P.2d 241 (Utah 1953), the court held that an occupant who had lived in a three-room motel unit for $21 / 2$ months could only be dispossessed by resort to UTAE CODE ANN. \$§78-36-1 to -11 (1953) -the unlawful detainer statute. The court noted as indicative of tenant status that: the unit was designed and equipped for permanent housekeeping; the occupant remained for a longer period than the ordinary transient; the unit was supplied the living needs of a home; the rent was payable bimonthly.

91. Green v. Shoemaker, 111 Md. 69, 73 Atl. 688 (1909). There, plaintiff occupied three rooms in a dwelling house. She had been on the premises nine months, and she and her family ate their meals with the owner of the house. It is uncertain whether this court was actually considering the situation in terms of "residence," because the opinion makes frequent references to the test of "exclusive possession."

92. Taylor v. Dean, 78 A.2d 382 (D.C. Mun. Ct. App. 1951). There, three families, including the owner's, occupied a six-room dwelling house. Bathroom, kitchen and dining room facilities were shared. The owner supplied utilities and paid repair bills. The families paid rent at monthly intervals.

93. Hundley v. Milner Hotel Management Co., 114 F. Supp. 206 (W.D. Ky. 1953). There, an occupant sued for wrongful eviction because of failure of the owner to give notice to quit. Held : the occupant was a tenant and entitled to notice. The court found these facts as indicative of a tenant relationship : occupant furnished own rooms; no maid service; occupant used rooms for housekeeping and prepared meals in them; occupant not a transient; occupant did some minor decorating and repairing; monthly rental. Sec also Washington Realty Co. v. Harding, 45 A.2d 785 (D.C. Mun. Ct. App. 1946), where the owner claimed breach of a sublease prohibition. Held: since the owner did not live on the premises and since some of the occupants in question had been on the premises for two or three years, there was enough evidence of breach to send the case to the jury. And see McBride v. Hosey, 197 S.W.2d 372 (Tex. Civ. App. 1946). There, a hotel occupant brought an action for wrongful eviction. Held: for owner. Though the occupant had been there over nine months, he was in arrears in rent and had been given four days notice to quit. Moreover, he had procured substitute accommodations at the first place he applied. And see Lambert v. Sine, 256 P.2d 241 (Utah 1953) (see facts cited in note 90 supra). 


\section{Property Lost by Fire and Theft}

When goods of a rental occupant are lost, either by theft or by destruction of the building by fire, the occupant frequently brings an action against the owner to recover their value. Usually the property is lost from the occupant's room, and neither party is negligent. ${ }^{94}$ Where by common law the innkeeper is held to be an insurer ${ }^{95}$ and where no statute limits his liability for the property in question, ${ }^{96}$ a guest may recover the full value of his lost property..$^{07}$ The lodger, however, may not recover. ${ }^{\mathrm{s}}$

Although seldom clearly expressed, the basic issue in these cases is which of two innocent parties should bear the risk of loss. ${ }^{00}$ Here again, permanency of residence should be of controlling importance. The occupant residing permanently on the premises has presumably been able to assess the nature of his rental dwelling as well as the integrity of the owner and his employees, while the transient has had no such opportunity. ${ }^{100}$ Moreover, the resident is in a position to make adequate arrangements for the safekeeping of his money and valuables. The transient, on the other hand, may be forced to leave his property in relatively accessible places. Accordingly, there is justification for allowing only the short-term occupant to recover for stolen goods from an innocent owner. In cases of accidental destruction of the premises by fire, not even a permanent resident may have been able to protect his possessions effectively. However, a tenant in an apartment building bears the risk of loss of his own property in such situations. ${ }^{101}$ The same reasons would seem to justify imposing the risk of loss from fire, as well as from theft, on the long-term occupant of a hotel or inn. ${ }^{102}$

94. See, e.g., Fay v. Pacific Improvement Co., 93 Cal. 253, 26 Pac. 1099 (1892); Gray v. Drexel Arms Hotel, 146 Iil. App. 604 (1909); Roberts v. Case Hotel Co., 106 Misc. 481, 175 N.Y. Supp. 123 (Sup. Ct. 1919).

95. See note $\mathbf{5 2}$ supra.

96. It has already been observed that many jurisdictions now have statutes limiting the common law liability of an innkeeper. See note 51 sipra. This discussion is concerned only with those situations where, either because there is no limiting statute or becsuse it is for some reason not applicable, the common law liability of the innkeeper is in force. For an example of one such situation, see Smith v. Dorchéster Hotel Co., 145 Wash. 344, 259 Pac. 1085 (1927).

97. See text at note 49 supra.

98. Ibid.

99. See Fay v. Pacific Improvement Co., 93 Cal. 678, 26 Pac 1099 (1891); Mrason v. Thompson, 9 Pick. 280, 20 Am. Dec. 471 (Miass. 1830).

100. See McIntosh v. Schops, 92 Ore. 307, 180 Pac. 593 (1919).

101. The general rule is that a tenant can only recover for goods lost by fire when the owner is proved negligent. See Cooper v. Lawson, 139 Mfich. 628, 103 N.W. 168 (1905) ; Grubbe v. Lein Realty Corp., 37 N.Y.S.2d 145 (N.Y. City Ct. 1941); Edwards v. Holeson, 189 Va. 948, 54 S.E.2d 857 (1949). See also cases collected in Annot, 66 A.L.R. 1393 (1930).

102. It has been argued that a hotel owner or innkeeper should bear the loss because he can adjust his rates to cover such contingencies. Fay v. Pacific Improvement Co., 93 Cal. 253, 26 Pac. 1099 (1891). This argument has merit when the loss is suffered by a short-term occupant who is paying at the regular transient rate. However, it seems of 
Yet only a minority of courts, in determining whether an occupant is a guest or a lodger, for purposes of recovery of lost property, consider permanency of residence. ${ }^{103}$ Instead, some focus attention upon whether the owner and the occupant had entered into a special contract regarding length of stay, price, or both. ${ }^{104}$ And many others consider decisive whether the rental unit was located in a hotel or in an apartment house. ${ }^{105}$

Courts which employ the special contract test have denied even the shortterm occupant the right to recover for lost goods if he has made such a contract. ${ }^{100}$ Under modern conditions, however, most individuals coming to hotels or tourist homes can, with preciseness, fix in advance the limits of their visit and the rate to be paid. A short-term occupant should not be held a lodger merely because he has chosen to make advance arrangements. Nor should a long-term resident be considered a guest because he has failed to make his desires explicit. ${ }^{107}$ The significance attributed to a special contract in loss of goods cases has been increasingly deemphasized in recent years. ${ }^{108}$

Those courts which consider the nature of the rental dwelling as determinative of the rights of the occupant have allowed long-term occupants of hotels and inns to recover as guests, ${ }^{100}$ reasoning that these occupants retain the

doubtful validity with respect to the long-term occupant who receives a special rate below that of the ordinary transient.

103. See Haff v. Adams, 6 Ariz. 395, 59 Pac. 111 (1899) ; Magee v. Pacific Improvement Co., 98 Cal. 678, 33 Pac. 772 (1893) ; Fay v. Pacific Improvement Co., 93 Cal. 253, 26 Pac. 1099 (1891); Gray v. Drexel Arms Hotel, 146 Ill. App. 604 (1909) ; Asseltyue v. Fay Hotel, 222 Minn. 91, 23 N.W.2d 357 (1946); Mason v. Hotel Grand Union, Inc, 41 N.Y.S.2d 309 (N.Y. City Ct. 1943); McIntosh v. Schops, 92 Ore. 307, 180 Pac. 593 (1919).

104. See Clifford v. Stafford, 145 Ill. App. 247 (1908); Vance v. Throckmorton \& Anderson, $68 \mathrm{Ky} .41,96 \mathrm{Am}$. Dec. 327 (1868); Meacham v. Galloway, 102 'Tenn. 415, 52 S.W. 859 (1899) ; Driskill Hotel Co. v. Anderson, 19 S.W.2d 216 (Tex. Civ. App. 1929) ; Daniel v. Hotel Pacific Pty., Ltd., [1953] Argus L. Rep. 1043.

105. See Pettit v. Thomas, 103 Ark. 593, 148 S.W. 501 (1912); Burdock v. Chicago Hotel Co., 172 Ill. 185 (1912); Layton v. Seward, 320 Mich. 418, 31 N.W.2d 678 (1948); Leon v. Kitchen Bros. Hotel Co., 134 Neb. 137, 277 N.W. 823 (1938); Hancock v. Rand, 94 N.Y. 1, 46 Am. Rep. 112 (1883); Roberts v. Case Hotel Co., 106 Misc. 481, 175 N.Y. Supp. 123 (Sup. Ct. 1919); Driskill Hotel Co. v. Anderson, 19 S.W.2d 216 (Tex. Civ. App. 1929).

106. See, e.g., Clifford v. Stafford, 145 Ill. App. 247 (1908) (contract for 1 week stay); Meacham v. Galloway, 102 Tenn. 415, 52 S.W. 859 (1899) (contract for 3 wceks stay); Daniel v. Hotel Pacific Pty., Ltd., [1953] Argus L. Rep. 1043 (group of occupants contracted for stays ranging from 9-21 days).

The existence of a special contract is not an accurate indication of an occupant's permanency of residence. See generally, Pettit v. Thomas, 103 Ark. 593, 148 S.W. 501 (1912); Hancock v. Rand, 94 N.Y. 1, 46 Am. Rep. 112 (1883); Jalie v. Cardinal, 35 Wis. 118 (1874).

107. See Daniel v. Hotel Pacific Pty. Ltd., [1953] Argus L. Rep. 1043, 1050 (dissenting opinion).

108. See, e.g., Layton v. Seward, 320 Mich. 418, 31 N.W.2d 678 (1948); Hart v. Milis Hotel Trust, 144 Misc. 121, 258 N.Y. Supp. 417 (N.Y. Munic. Ct. 1932) ; Smith v. Dorchester Hotel Co., 145 Wash. 344, 259 Pac. 1085 (1927).

109. See, e.g., Burdock v. Chicago Hotel Co., 172 Ill. App. 185 (1912) (nine months 
character of travelers regardless of the length of their stay. ${ }^{110}$ Granting recovery to such occupants may be justified on a theory that the owner is in a better position to absorb the loss. ${ }^{111}$ However, this approach seems unduly generous to permanent occupants, who would not be able to recover if they were tenants or lodgers in apartment buildings. ${ }^{112}$ Moreover, it overlooks the fact that both guests and lodgers may occupy the same rental dwelling and maintain differing legal relationships with the owner. ${ }^{113}$

A third group of courts has denied recovery for loss of goods to occupants residing in rental dwellings for periods from several months to several years by classifying such occupants as lodgers. ${ }^{114}$ These courts, however, have allowed shorter term occupants to recover as guests. ${ }^{115}$ In addition to the occupant's length of stay, they have considered as factors indicating permanency of residence the absence of another home, ${ }^{110}$ and weekly and monthly rental payments. ${ }^{117}$ For reasons already stated, ${ }^{118}$ this approach seems the most equitable method of distributing the risk of loss of goods from fire and theft.

Negligence of the owner is a prerequisite to recovery by a lodger for lost belongings. ${ }^{119}$ Courts have followed orthodox tort principles to determine whether the owner breached his duty of protecting the occupant's property.

stay in hotel); Layton v. Seward, 320 Mich. 41S, 31 N.W.2d 678 (1948) (four months stay in hotel); Leon v. Kitchen Bros. Hotel Co., 134 Neb. 137, 277 N.W. $\$ 23$ (1938) (several months stay in hotel; no other home); Hancock v. Rand, 94 N.Y. 1, 46 Am. Rep. 112 (1883) (same); Driskill Hotel Co. v. Anderson, 19 S.W.2d 216 (Tex. Civ. App. 1929) (one year stay in hotel). But of. Roberts v. Case Hotul Co., 105 Misc. 431, 175 N.Y. Supp. 123 (Sup. Ct. 1919) (one week stay in apartment house; held lodger).

110. See cases cited note 109 supra.

111. See Fay v. Pacific Improvement Co., 93 Cal. 253, 26 Pac. 1099 (1891).

112. Murray v. Hagens, 143 So. 505 (La. App. 1932); Gibson v. Von Glahn Hotel Co., 185 N.Y. Supp. 154 (Sup. Ct. 1920); Wells v. West, 212 N.C. 656, 194 S.E 313 (1937).

113. See note 5 supra.

114. Gray v. Drexel Arms Hotel, 146 Ill. App. 604 (1909) (four months); Asseltyne v. Fay Hotel, 222 Minn. 91, 23 N.W.2d 357 (1946) (several months); Mrason v. Hotel Grand Union, Inc, 41 N.Y.S.2d 309 (N.Y. City Ct. 1943) (two and one-half years); MIcIntosh v. Schops, 92 Ore. 307, 180 Pac. 593 (1919) (two years).

115. Magee v. Pacific Improvement Co., 98 Cal. 678, $33 \mathrm{Pac} .772$ (1893) (ten days); Fay v. Pacific Improvement Co., $93 \mathrm{Cal} .253,26 \mathrm{Pac} 1099$ (1S91) (a little over a week); Moon v. Yarian, 147 Ill. App. 383 (1909) (two months); Lusk v. Belote, 22 Minn. 468 (1876) (one month); Hart v. Mills Hotel Trust, 144 Misc. 121, 258 N.Y. Supp. 417 (N.Y. Munic. Ct. 1932) (three weeks).

116. See Haff v. Adams, 6 Ariz. 395, 59 Pac 111 (1899); Mrason v. Hotel Grand Union, Inc., 41 N.Y.S.2d 309 (N.Y. City Ct. 1943).

117. See Asseltyne v. Fay Hotel, 222 Minn. 91, 23 N.W.2d 357 (1946); MicIntosh v. Schops, 92 Ore. 307, $180 \mathrm{Pac} 593$ (1919). Paying by the day is more indieative of the transient guest.

118. See p. 405 sipra.

119. See note 49 supra. Proving negligence on the part of an innkeeper may also be important. Negligence by him or his servants will suspend the applieation of liabilitylimiting statutes. See note $\mathbf{5 0}$ supra. Furthermore, it is nccessary in some jurisdictions to prove an innkeeper negligent even in the absence of statute. See note 52 supra. 
Where goods have been stolen from the rooms of a ladger, courts have considered the following facts as evidence that the owner was not negligent: the owner exercised care in selecting servants $\mathbf{;}^{\mathbf{1 2 0}}$ the rented room had no outside approaches $;^{121}$ clerks, elevator operators, or watchmen were on duty at all times ${ }^{122}$ notices of the existence of a safe were prominently posted..$^{123}$

In cases of theft of an occupant's property from parts of a rental dwelling other than his rooms, courts have correctly stressed the owner's custody over the property at the time of its disappearance rather than the occupant's status. ${ }^{124}$ Thus, where money disappeared from a hotel safe, ${ }^{125}$ and a car was stolen from a hotel garage to which only the owner had a key, ${ }^{126}$ the losses were presumed to have occurred by the theft or negligence of the innkeeper or his servants. Courts have also held agreements between the parties with respect to duties assumed or negatived to be important in determining liability ${ }^{127}$

\section{Personal Injuries Sustained On Rented Premises}

Exclusiveness of possession underlies both judicial refusal to impose liability on owners for injuries to tenants and imposition of stuch liability for injuries to lodgers and guests. Since an owner has no right to enter the rooms of a tenant during occupancy, courts reason that no duty of repair can be placed upon him $;^{128}$ since the owner retains the right to enter the premises of a lodger or guest, he is charged with the duty of keeping these rooms in reasonable repair. ${ }^{129}$ Following the traditional exclusiveness test, courts have allowed an occupant to recover where the owner supplied maid service and utilities and re-

120. See Gray v. Drexel Arms Hotel, 146 Ill. App. 604 (1909).

121. Ibid.

122. Ibid.; Mason v. Hotel Grand Union, Inc., 41 N.Y.S.2d 309 (N.Y. City Ct. 19-13); Gibson v. Von Glahn Hotel Co., 185 N.Y. Supp. 154 (Sup. Ct. 1920).

123. See Mason v. Hotel Grand Union, Inc., 41 N.Y.S.2d 309 (N.Y. City Ct. 1943).

124. See, e.g., Goodyear Tire \& Rubber Co. v. Altamont Springs Hotel Co., 206 Ky. 494, 267 S.W. 555 (1925) ; Layton v. Seward, 320 Mich. 418, 31 N.W.2d 678 (1948).

125. In Layton v. Seward, supra note 124 , the occupant deposited $\$ 3500.00$ at the hotel desk in an envelope provided by the owner of the hotel. The owner put the money in a safe from whence it disappeared. The court held that on the basis of these facts and in the absence of any other explanation, the loss is presumed to have occurred by the theft or negligence of the owner or his employees.

126. In Goodyear Tire and Rubber Co. v. Altamont Springs Hotel Co., 206 Ky. 494, 267 S.W. 555 (1925), an occupant who was under a special contract with a hotel for one month kept his car in the hotel garage; the car was stolen. Evidence showed that the hotel owner had control over the car at the time it was stolen and that there was no contributory negligence. The hotel owner was held liable.

127. In Vigeant v. Nelson, 140 III. App. 644 (1908), a trunk belonging to a lodger was stolen from the storage room in a hotel. The owner had assumed care and custody of the trunk. However, the court held the owner free from negligence because of the presence of a sign in the hotel hall reading: "Baggage or wearing appatcl left for storage will receive careful attention at the owner's risk."

128. See, e.g., Coggins v. Gregorio, 97 F.2d 948 (10th Cir. 1938); 1 Tirmany, LandLORD AND TENANT 574 (1912).

129. See, e.g., Marden v. Radford, 229 Mo. App. 789, 84 S.W.2d 947 (1935). 
tained a key to the occupant's hotel rooms, ${ }^{130}$ and they have denied recovery where the premises were unfurnished and the owner provided no maid service and had no right of entry. 131 However, many of the factors indicating that the occupant is not in exclusive possession are irrelevant to the basic issue in these cases: which party had the duty of repair?

All courts, even those following the exclusiveness test, have given some attention to the question of assumption of the duty to repair. Thus, one court in granting recovery to an occupant who did not enjoy exclusive possession, weighed the fact that the owner considered himself under such a duty. ${ }^{132}$ And where the owner had promised to repair when notified of defects, even a tenant was allowed to recover. ${ }^{133}$ Similarly, recovery was denied where an occupant with exclusive possession had rented with the understanding that he would have the duty of repair. ${ }^{134}$ Courts have also emphasized the proved intent of the parties to enter into a landlord-tenant relationship as indicative of assumption of duty by the occupant. ${ }^{135}$ Since courts have usually found an explicit duty of repair in the same party upon whom such duty would have been imposed under the exclusiveness test, ${ }^{136}$ the results in these cases appear sound. However, slavish adherence to the exclusiveness test may yield unfortunate results in cases where no assumption of duty can be established. ${ }^{137}$

130. Ibid. In Marden, the leading case in this field, the occupant was held a lodger and granted recovery for injuries sustained in a fall caused by an inadequately supported drainboard.

131. See Coggins v. Gregorio, 97 F.2d 948 (10th Cir. 1938) (occupant injured by failing plaster); Martin v. Shryock Realty Co., 236 Mo. App. 1265, 163 S.W.2d 804 (1942) (occupant injured by fall on sharp, protruding bathroom fixture).

132. See MIarden v. Radford, 229 A1o. App. 7\$9, 84 S.W.2d 947 (1935); note 130 supra.

133. See Garner v. La Marr, \&8 Ga. App. 364, 76 S.E.2d 721 (1953), 6 BAyzon L. Rev. 228 (1954) (falling plaster injured occupants).

134. See Coggins v. Gregorio, 97 F.2d 948 (10th Cir. 1938). See also Zavalney v. Donovan, 70 Cal. App. 2d 182, 160 P.2d 558 (1st Dist. 1945), where a court denied recovery to a tenant for injuries caused by a splintered faucet handle. The tenant had been aware of the defective handle when he rented the premises eleven months previously and had failed to notify the landiord of the defect.

135. See Zavalney v. Donovan, 70 Cal. App. 2d 182, 160 P.2d 558 (1st Dist. 1945). See also Martin v. Shryock Realty Co., 236 M1o. App. 1265, 163 S.IV.2d 804 (1942) (contract between the parties indicated landlord-tenant relationship).

In Cottmire v. 181 East Lake Shore Drive Hotel Co., 330 Ill. App. 549, 71 N.E.2d 823 (1947), the court held that a permanent resident in a hotel could recover for injuries caused by a defective bathroom fixture under an Illinois statute which, the court felt, made all hotel occupants "guests" regardless of length of stay.

136. See, e.g., Míarden v. Radford, 229 M1o. App. 789, 84 S.W.2d 947 (1935) (owner admitted duty to repair rooms of lodger); Coggins v. Gregorio, 97 F.2d 948 (10th Cir. 1938) (tenant understood that he was to do all work necessary to keep the apartment in repair). See also Miartin v. Shryock Realty Co., 236 11o. App. 1265, 163 S.W.2d 804 (1942) (owǹer never assumed any duty to repair premises of tenant).

137. If, by application of the exclusiveness test, the occupant is held to be a tenant, courts are justified in absolving the owner; since he has no right to enter, the owner can have no duty to repair. However, when an occupant is a lodger under the exclusiveness 
Certain elements of the exclusiveness test, such as whether maid or janitorial service was supplied or whether the owner had the right of inspection, are important in determining liability when neither party has clearly assumed the duty of repair, since they indicate whether the owner had or should have had knowledge of defects on the premises. In addition to these facts, courts should consider the occupant's permanency of residence: a long-term resident has presumably had an opportunity to inspect his rooms and repair defects, whereas the transient guest has had no such opportunity. ${ }^{138}$ However, neither exclusiveness nor permanency factors should be considered controlling when owner or occupant has explicitly undertaken or negatived a duty of repair.

\section{Conclusion}

The categorizations of tenant, lodger, and guest have too frecuently become the end rather than the means of judicial inquiry ${ }^{130}$ in cases involving the rights and duties of owners and occupants of rented premises. ${ }^{140}$ Courts have stressed, in all types of actions, an unchanging aggregate of facts for the purpose of categorizing the occupant; from these categories, consequences have followed as a matter of law. Since the underlying bases of the actions involving an owner-occupant relationship are so widely varied, the relevant facts also vary. But the courts, by emphasizing the same set of facts in all types of cases, have made no effort to discriminate between those which are important in a particular action and those which are not. Facts such as permanency of residence, although often ignored, should almost always be considered significant. Others, such as whether the owner supplied utilities or retained a key to the rented premises, have become meaningless under modern conditions and should be discarded. ${ }^{141}$ Courts, when categorizing an occupant in order to

test, the owner should not necessarily be held to have assumed the duty of repair, since the fact that the owner has the right to enter does not prevent an assumption of dity by the occupant or a waiver by the occupant of the owner's duty to repair. See also note 58 supra.

138. For cases in which length of stay is considered important, see Duncan v. Chelsea Hotel Co., 326 Ill. App. 241, 61 N.E.2d 769 (1945) (seven years residence-recovery denied) ; Fonyo v. Chicago Title \& Trust Co., 296 Ill. App. 227, 16 N.E.2d 192 (1938) (same; nearly two years residence); Martin v. Shryock Realty Co., 236 Mo. App. 1265, 163 S.W.2d 804 (1942) (same; three and one-half years residence).

139. See McDougal \& Haber, Property, Wealtir, Land 342, note (b) (1948).

140. It is interesting to note that the categorizations have never been applied to business premises. 1 TIFFANY, LANDLORD AND TENANT 34 (1912). Such an application would perhaps convert the great mass of business occupants into lodgers under the exclusiveness test, since few provide for their own cleaning services or utilities. Thus, perhaps the failure to extend the categorizations to business premises is because the occupant would then be entitled to no notice to quit, no effective sublease prohibitions would be possible, and the owner of the property would be under a duty to keep the premises in repair.

141. The question of who supplied utilities was perhaps a legitimate subject of inquiry in the days when it was necessary for the owner to enter the occupant's rooms to perform such services as supplying coal, firewood, and water. Today, however, the owner frequently "supplies" utilities by simply paying the monthly bill with part of the rental 
determine his rights, should consider only those facts relevant to the action being brought. In this way both owner and occupant will be amply protected.

which he receives from the occupant. Nevertheless, even some of the most recent cases still consider that the supplying of utilities by the owner was a significant fact in determining lodger or guest status. See Hundley v. Milner Hotel Management Co., 114 F. Supp. 206 (W.D. Ky. 1953) ; Lambert v. Sine, 256 P.2d 241 (Utah 1953).

The exclusiveness and transiency tests have themselves been attacked as outmoded. See 1 Aarerican Law of Property $\$ 3.7$ (Casner ed. 1952) ; Daniel v. Hotel Pacific Pty., Ltd., [1953] Argus L. Rep. 1043, 1047 ("The root of the trouble is that we are applying to present-day complex conditions a concept that originated in, and applicd to, a much simpler state of society."). 